\title{
The Aesthetic as Mirror of Faith in Kierkegaard's Fear and Trembling
}

\section{Genia Schönbaumsfeld, University of Southampton}

'Every individual who does not live either poetically or religiously is obtuse.'

\section{Introduction}

One of the most intractable issues in Kierkegaard scholarship continues to be the question of what one is to make of the relation between infinite resignation and faith in Fear and Trembling (FT). Most commentators follow Kierkegaard's pseudonymous author, Johannes de Silentio, in claiming that progression to faith is a 'linear' process that requires infinite resignation as a first step $^{2}$. The problem with such a reading is that it leads to paradox: it seems to require attributing to the 'knight of faith' two inconsistent belief-attitudes at the same time.

In respect to the biblical story of Abraham from Genesis, the ostensible focal point of FT, the problem is particularly pronounced. If we espouse the 'linear model' that de Silentio appears to be advocating, this seems to require that Abraham must both believe that he will have to sacrifice Isaac (since this is what God allegedly commands), and, hence, that Isaac will die (the stance of 'infinite resignation'), while simultaneously being convinced that he will not have to sacrifice Isaac, and, hence, that Isaac will not die (the stance of faith) ${ }^{3}$. Cross spells out why this is obviously incoherent: 
It means attributing a radically and patently untenable position to de Silentio (and, possibly, to Kierkegaard). The problem isn't just that a conception of faith as involving the simultaneous and explicit affirmation of contradictory propositions is wildly implausible as an ideal (although it is that). The problem is that such a conception is incoherent on its face. There is nothing that it is to hold contradictory beliefs in this manner; to hold the one just is to deny the other (Cross 1999: 238) ${ }^{4}$.

Since Cross is surely right that there is nothing that it is to hold contradictory beliefs in this way, we need to find a reading of the text that can avoid this consequence. To this end, I will argue that faith is not a 'two-step' procedure that requires that one pass through infinite resignation first. Rather, infinite resignation and faith are two completely different and distinct attitudes that one can take to life and the world ${ }^{5}$. Nevertheless, this is compatible with maintaining that a form of resignation is a necessary element of faith. The difference is that the kind of resignation that is a part of faith is not at all the same stance as what de Silentio calls infinite resignation - an important distinction that isn't considered by those who endorse the linear model or versions thereof, such as 'annulled possibility' readings. For the latter just strive to 'cancel' the first movement in the two-step process ${ }^{6}$, rather than challenging this model altogether.

So what I'm going to propose instead is that, contrary to what de Silentio sometimes seems to intimate, faith isn't infinite resignation plus another 'absurd' step that somehow gets us back to where we started from. Rather, the ostensible 'double movement' of faith is really a single movement that completely transforms one's relation to the finite. In order to be able to see this, however, we need to turn to two other Kierkegaardian voices for guidance: to 
Johannes Climacus, the pseudonymous author of Concluding Unscientific Postscript (CUP) ${ }^{7}$, as well as, surprisingly perhaps, to the aesthete A, whose papers constitute the first part of Either/Or. Given that Johannes Climacus, in 'A Glance at a Contemporary Effort in Danish Literature' (in CUP), makes himself out to be the would-be author ${ }^{8}$ of the entire pseudonymous production before CUP, and therefore also of Either/Or, this seems entirely legitimate. In this respect it is interesting to note that the writer of Fear and Trembling shares his first name both with Johannes Climacus and with Johannes, the Seducer (the Germanic version of Don Giovanni ${ }^{9}$ ), whose diary forms the ultimate part of the aesthete's compendium. Since Kierkegaard devoted enormous effort to his pseudonymous strategy, I would suggest that this cannot be entirely accidental ${ }^{10}$. But even if I am wrong about this, the plausibility of the interpretation that I will defend does not in any way depend on accepting this point.

For what the juxtaposition with the other Johanneses is meant to show is that faith's alleged paradoxicality is only apparent and that the element of resignation that constitutes an aspect of it actually bears some resemblances to what the aesthete has in mind when he speaks, in Either/Or, of throwing hope overboard in order to make possible an artistic way of life. In other words, on my interpretation, the knight of faith does not need to adopt two contradictory belief-attitudes at the same time (or constantly to 'annul' one of them), but must rather practice a form of spiritual discipline that in some ways mirrors his aesthetic counterpart's, and that allows him, as the author of CUP in turn makes clear, to relate to the finite in the right way - that is to say, 'relatively'. Such a stance, however, only becomes available once we have 'died to immediacy' - once the 'miserable hope' (FT 66) ${ }^{11}$ that our worldly desires will be fulfilled has been cast out ${ }^{12}$. It is this process of 'de-absolutizing' the finite that constitutes the element of resignation that is a vital part both of the aesthetic life and the life of the knight of faith ${ }^{13}$. But whereas the aesthete, by practicing the art of being 
able to recollect and forget at will, regains the finite by turning it into art, the knight of faith's transformation of the finite is effected by his simultaneously relating himself absolutely to the absolute telos and relatively to relative ends (CUP 431). Once this is made perspicuous, the apparent need to square the circle in FT - a temptation that de Silentio, qua outsider to faith, himself at times succumbs to - dissolves. The lessons that we can learn from this investigation ramify beyond exegetical concerns by giving us a clearer picture of the different ways in which one can respond to human suffering and life's vicissitudes.

\section{The Poet of Chance}

Since I'm going to argue that the aesthetic way of life mirrors, in some important ways, the life of the knight of faith, it is probably a good idea to start off by explaining the 'theory, ${ }^{14}$ that lies at the heart of the aesthete's outlook. The aesthete is an amoralist who has lost faith in the existence of absolute values of any sort and therefore regards life as entirely devoid of meaning. Consequently, he believes that the only possible way of responding to this predicament is by manufacturing meaning for oneself. Given that both an ethical and a religious life would, on the aesthete's view, require, as Wittgenstein says, the 'coercive power of an absolute judge, ${ }^{15}$, and the aesthete believes that there can be no such thing ${ }^{16}$, the only genuinely available existential possibility is to transform life into art thereby giving it aesthetic value ${ }^{17}$. But such a life, according to Kierkegaard's pseudonymous author, only becomes available to one once one has mastered the art of being able to recollect and forget at will - a skill that $\mathrm{A}^{18}$ calls the Archimedean point with which one can lift the whole world (Either/Or 295). 
Prima facie, the very idea that recollecting and forgetting could be subject to the will is naturally going to strike one as just as paradoxical as the notion that the knight of faith both has to believe and not believe that he must give up what he cares about most. Appearances can be deceptive, however, for the aesthete distinguishes between remembering - which is not subject to the will (otherwise all students would pass their exams) - and recollecting, which, according to the aesthete, is a poetic form of purposely calling events to mind that can be brought under the jurisdiction of the will if one relates to actuality (how things are) in the right way. That is to say, although the aesthete is a fan of all sorts of hedonic pursuits, he nevertheless recommends moderation in all things enjoyed, as over-indulgence would impair one's capacity to experience actuality in such a way that recollecting and forgetting can become two sides of the same coin:

To forget - this is the desire of all people, and when they encounter something unpleasant, they always say: If only I could forget! But to forget is an art that must be practiced in advance. To be able to forget always depends upon how one remembers, but how one remembers depends upon how one experiences actuality. The person who runs aground with the speed of hope will recollect in such a way that he will be unable to forget. Thus nil admirari [marvel at nothing] is the proper wisdom of life. No part of life ought to have so much meaning for a person that he cannot forget it any moment he wants to; on the other hand, every single part of life ought to have so much meaning for a person that he can remember it at any moment. The age that remembers best is also the most forgetful: namely childhood. The more poetically one remembers, the more easily one forgets, for to remember poetically is really actually only an expression for forgetting. When I remember poetically, my experience has already undergone the change of having lost everything painful. In order to be able to recollect in this way, one must be very much aware of how one lives, especially of how one enjoys. If one enjoys indiscriminately to the very end, if one continually takes the utmost that enjoyment can give, one will be unable either to recollect or to forget (Either/Or 293). 
In other words, the whole secret of living artistically consists in developing the right kind of relation to one's life experiences, which only becomes possible once one has let go of this most untrustworthy of shipmasters - hope (ibid.).

The reasons for this appear to be the following. The aesthete believes that we live in a brutely contingent world where it is a matter of chance whether things go our way or not. Since suffering results from having our desires thwarted, the best course of action consists in trying to make oneself independent of fate - that is to say, not to have one's happiness depend on whether our desires are fulfilled or not. How is that so much as possible? The aesthete would say by ceding one's stake in human affairs in the sense that one is no longer invested in a particular outcome ${ }^{19}$. If I no longer hope for such-and-such a course of events to come to pass, I will not be disappointed if it doesn't. Hope and emotional investment consequently go together - I only hope for the things that I genuinely care about. If I therefore loosen my demands on actuality by throwing hope overboard and no longer having the relevant investments, I will be able to enjoy the experiences life presents to me without being disappointed that it is not giving me the ones I thought I wanted.

This is not to recommend a form of stoicism, because what the aesthete desires is still to get the maximum artistic enjoyment out of life. But this enjoyment does not consist in having one's hopes and wishes fulfilled - as this is to leave oneself exposed to the vagaries and cruelties of chance - it is rather a function of being able to derive aesthetic pleasure from whatever one might happen to experience ${ }^{20}$. This is why A says that 'when a person has perfected himself in the art of forgetting and the art of recollecting in this way, he is then able to play shuttlecock with all existence' (Either/Or 294). In other words, once I'm no longer teleologically invested in what I experience (in the sense of wanting to bring about a certain end), I can see the whole of life as a potential source of aesthetic opportunity. 
Of course such a life is only possible if I don't form any genuine and meaningful attachments - if I forgo commitments of any kind ${ }^{21}$. Consequently, A warns against friendship and marriage, and any other life relationship by which one can become many (Either/Or 297). But this does not mean that one should live without contact with people, or, indeed, without engaging in erotic pursuits. As the aesthete says, 'the erotic, too, ought to have infinity - but a poetic infinity that can just as well be limited to an hour as to a month' (Either/Or 297-8).

Since the aesthete is not interested in giving permanence to any of his experiences, as this would curtail his freedom and limit his potential to explore new possibilities, he is able to regard himself as the 'poet of chance' (Either/Or 327), who is, in principle, able to use whatever life happens to provide as raw material that can be transformed into art. But just as a sculptor needs to develop his stone-hewing abilities say, so the artist of life needs to work on himself in such a way that every part of his existence has so much meaning for him that he can recollect it at any moment, while taking care to ensure that no part of life has so much meaning that he cannot forget it any moment he wants to. Once the aesthete has become proficient at this delicate balancing act by never allowing himself to be completely overpowered by an experience, forgetting and recollecting end up becoming almost indistinguishable from one another: the aesthete is able, at any time, to recall an experience and to dwell on its aesthetically pleasing aspects, while also being able to forget it in the sense that it will not continue to trouble him when he turns away to focus on something else.

\section{Frogs, Knights and Ballet Dancers}


Before we can discuss the relation between the aesthete and the knight of faith, we need to turn to Johannes de Silentio's presentation of the connexion between infinite resignation and faith in FT. The reason why Johannes is positively obsessed with this distinction is that he believes that it can throw some light on the remarkable faith of Abraham who was tried by God by being asked to sacrifice his only son, Isaac, in Genesis 22 .

We have already encountered the problem with de Silentio's view of Abraham's situation in the introduction: it seems that in order to comply with God's command, Abraham has to be prepared to give up Isaac - that is to say, believe that he will have to sacrifice him while faith, the only thing that, according to Johannes, prevents Abraham from being branded a potential child murderer, appears to require the opposite: the belief that the sacrifice will not ultimately be demanded of him. This raises the central conundrum of Fear and Trembling what is it that Abraham actually believes, and how does he manage to believe it?

Interestingly, Kierkegaard's pseudonymous author himself seems to say conflicting things about this question, which is perhaps unsurprising given that he regards himself as an outsider to faith. On the one hand, he is keen to emphasize that Abraham continues to have faith that Isaac will be spared:

But what did Abraham do? He arrived neither too early nor too late. He mounted the ass, he rode slowly down the road. During all this time he had faith, he had faith that God would not demand Isaac of him, and yet he was willing to sacrifice him if it was demanded (FT 35-6) ${ }^{22}$. 
On the other hand, Johannes appears to insist that the knight of faith - of which Abraham is an extraordinary exemplar - must pass through infinite resignation first, an attitude that seems to require that one resign oneself to the complete loss of what one loves most: 'Infinite resignation is the last stage before faith, so that anyone who has not made this movement does not have faith, for only in infinite resignation do I become conscious of my eternal validity, and only then can one speak of grasping existence by virtue of faith' (FT 46).

This of course raises the question, as we have already seen, of how one can renounce something (or someone) and at the same time believe that the sacrifice will not, in the end, have to be made, or that what has been sacrificed will be restored. But before we can make any headway with this question, we need to get a bit clearer about what, exactly, the distinction between infinite resignation and faith amounts to, and here the following passage proves helpful:

It is supposed to be the most difficult feat for a ballet dancer to leap into a specific posture in such a way that he never once strains for the posture but in the very leap assumes the posture. Perhaps there is no ballet dancer who can do it- but this knight [the knight of faith] does it. Most people live completely absorbed in worldly joys and sorrows; they are benchwarmers who do not take part in the dance. The knights of infinity are ballet dancers and have elevation. They make the upward movement and come down again; and this, too, is not an unhappy diversion and is not unlovely to see. But every time they come down, they are unable to assume the posture immediately, they waver for a moment, and this wavering shows that they are aliens in the world. It is more or less conspicuous according to their skill, but even the most skilful of these knights cannot hide this wavering. One does not need to see them in 
the air; one needs only to see them the instant they touch or have touched the earthand then one recognizes them. But to be able to come down in such a way that instantaneously one seems to stand and to walk, to change the leap into life into walking, absolutely to express the sublime in the pedestrian-only that knight can do it, and this is the one and only marvel (FT 41).

De Silentio distinguishes between three different types of people in this passage. The 'benchwarmers', who do not take part in the dance, because they live completely absorbed in worldly joys and sorrows, and the 'ballet dancers', whom Johannes divides into two kinds according to skill: the knights of infinite resignation, who possess 'elevation', but waver (or wobble) when they come out of their jump, and the knights of faith who are so accomplished that they are immediately able to assume the next position without betraying the slightest hint of the enormous effort required to do this.

It is interesting for our purposes that the author of FT deems both 'knights' artists (ballet dancers), while dubbing those who unreflectively remain absorbed in the finite (in worldly joys and sorrows) 'benchwarmers' (Oversidderne ${ }^{23}$ ). This would already seem to mark the knights out as possessing some kinship with the aesthete, the self-proclaimed 'poet of chance', who would doubtlessly also regard the 'benchwarmers' with disdain. Nevertheless, and despite holding this worldly absorption in contempt, de Silentio also appears to regard a flight from the world as constituting a serious flaw, otherwise he wouldn't chastise the knights of infinite resignation for being aliens in the world, who betray their estrangement from the finite by wavering. Consequently, it seems that only the knights of faith possess the right attitude to life by neither having their whole life in worldly concerns, 
nor by rejecting them (as the knights of infinity do). So, we need to find out how it is possible to acquire this marvellous ability.

The best way to do this is by examining more closely the distinction between the knights of faith and infinite resignation, and those who do not take part in the dance. To this end, de Silentio introduces the story of the lad and the princess in the 'Preliminary Expectoration':

A young lad falls in love with a princess, and this love is the entire substance of his life, and yet the relation is such that it cannot possibly be realized, cannot possibly be translated from ideality into reality. Of course the slaves of the finite, the frogs in the swamp of life, scream: That kind of love is foolishness; the rich brewer's widow is just as good and solid a match. Let them go on croaking in the swamp (FT 41-2).

The frogs that go on croaking in the swamp of life seem to be the same kinds of people previously referred to as the benchwarmers: they are the 'slaves of the finite' who believe that it is possible to outwit fate by going for prudential considerations - if I can't have what I want, then I just need to start wanting what I can have (for example, the rich brewer's widow). De Silentio regards such an attitude of shrewdness as a contemptible form of bourgeois philistinism, which, he thinks, reveals one as incapable of caring about anything higher; as incapable of having any ideals.

The aesthete would presumably agree with this and probably add that prudence, like hope, leaves one at the mercy of chance - one's prudential calculations might come off, or they might not. Hence, there is, ultimately, no such thing as 'outwitting fate'. As long as I 
remain invested in the finite, I'm going to be disappointed if things don't go my way, even if I try, as it were, to 'diversify' my portfolio in order to insure against potential losses (FT 43).

But if this response to life's vicissitudes is no good, what, then, are the alternatives? One possibility, according to de Silentio, is infinite resignation: the lad gives up hope of ever having the princess, but without thereby renouncing his love: 'The desire that would lead him [the lad] out into actuality but has been stranded on impossibility is now turned inward, but it is not therefore lost, nor is it forgotten' (FT 44). Instead, it continues to exist within the lad in transformed form; he perhaps sublimates it into a love of God.

Consequently, whatever the princess now does, is of no concern to the lad. From the moment he has made the movement of infinite resignation, the real princess is lost to him, for he takes refuge in an ideal ${ }^{24}$. In this respect, the lad renounces the actual princess, but manages to hold onto a sublimated version of his love; and this movement, despite its incumbent pain, reconciles him with existence: 'Infinite resignation is that shirt mentioned in an old legend. The thread is spun with tears, bleached with tears; the shirt is sewn in tears but then it also gives better protection than iron and steel' (FT 45). This shirt gives better protection than iron and steel, because once one has given up the wish that was the whole substance of one's life, one has, in effect, also renounced the whole finite world. One has given up hope that the world can ever give one what one wants and this, in a sense, inoculates one against further suffering.

Naturally, the price that one pays for this peace and security is high. For it is not just the actual princess who is lost to the lad, but all worldly concerns. This is why Johannes calls the knights of infinity 'aliens' - their acts of renunciation have left them estranged from finite matters, and this they betray by wobbling when they land. For this reason, Anti-Climacus, the 
Christian author of Kierkegaard's The Sickness unto Death, would probably go further than Johannes and call infinite resignation a form of despair that needs to be overcome by faith ${ }^{25}$.

But what is it that the knight of faith does better than his fellow dancer? According to de Silentio, the knight of faith does exactly the same as the other knight, he 'infinitely renounces the love that was the substance of his life' (FT 46), but then 'he makes one more movement even more wonderful than all the others', for he says to himself: 'nevertheless I have faith that I will get her - that is, by virtue of the absurd, by virtue of the fact that for God everything is possible' (ibid.).

Johannes could hardly have put things more infelicitously. Not only does he seem to be expounding, in this passage, what I have called a 'linear model' of faith that appears to require adopting two inconsistent belief-attitudes in quick succession, he also seems to be saying that the second attitude involves an 'absurd' appeal to a kind of deus ex machina who makes sure that we get what we want after all. This is strange, for it makes Johannes' conception appear very close, at this point, to a view that elsewhere he criticizes, namely that of the person who remains stuck in 'miserable hope' and who thinks 'it's possible, certainly' $\left(\right.$ FT $\left.66^{26}\right)$. Furthermore, and to make matters worse, the deus ex machina idea - the thought that God 'directly' intervenes in his creation as a 'master of the universe' figure might, in order to bring about a certain result for us - is dismissed as paganism and idolatry by Climacus who rejects the notion of an (even in principle) 'directly perceivable' God. And if Climacus is right that God is not 'directly perceivable', then neither are His actions or His works (qua 'direct interventions'):

'The direct relationship with God is simply paganism...All paganism consists in this, that God is related directly to a human being, as the remarkably striking to the 
amazed...Nature, the totality of creation, is God's work, and yet God is not there, but within the individual human being there is a possibility (he is spirit according to this possibility) that in inwardness is awakened to a God-relationship, and then it is possible to see God everywhere' (CUP 243-47) ${ }^{27}$.

If Climacus, who seems to know a bit more about faith than de Silentio does and who is also FT's would-be author, is right about this, then what has gone wrong in de Silentio's presentation? I would suggest that de Silentio, given his outsider status but clear enthusiasm for the subject, is simply prone, at times, to get a bit carried away ${ }^{28}$. For immediately after the infelicitous passage just cited, we get this:

The absurd does not belong to the differences that lie within the proper domain of the understanding. It is not identical with the improbable, the unexpected, the unforeseen. The moment the knight executed the act of resignation, he was convinced of the impossibility, humanly speaking; that was the conclusion of the understanding, and he had sufficient energy to think it. But in the infinite sense it was possible, that is, by relinquishing it, but this having, after all, is also a giving up (FT 46-7).

This passage clearly militates against the deus ex machina conception, as God's intervening to grant the knight of faith's wish would be identical with the 'improbable, the unexpected, the unforeseen'. Furthermore, it is incompatible with de Silentio's claim that the possibility exists only in the 'infinite sense', which is why de Silentio is adamant that a young girl who remains steadfastly convinced that she will get her beloved no matter how small the empirical 
odds, is not a knight of faith (FT 47) ${ }^{29}$. But if this is right, then believing 'on strength of the absurd' cannot entail believing that the very same finite ends that were previously resigned will be restored to you by an act of God. Rather, de Silentio is suggesting, possibility in the 'infinite sense' is a relinquishing - the 'having' of faith also a 'giving up.' What does this mean?

It is here that the comparison with the aesthete proves useful. Both the knight of infinite resignation and the knight of faith throw 'miserable hope' overboard just as the aesthete does. It is only the frogs in life's swamp - the slaves of the finite - who continue to hope for the fulfilment of their wishes, and who close their eyes to the fragility (possibility?) of human happiness by putting their faith in chance. But whereas the knight of infinity takes refuge in a sublimated ideal world that has nothing to do with actuality, the knight of faith manages simultaneously to give up and to retain the finite. It is this simultaneous movement that Johannes seems not to understand, and that he consequently gives us a confused picture of $^{30}$ :

But this movement [of faith] I cannot make. As soon as I want to begin everything reverses itself, and I take refuge in the pain of resignation. I am able to swim in life, but I am too heavy for this mystical soaring. To exist in such a way that my opposition to existence constantly expresses itself as the most beautiful and assured harmony with it - this I cannot do (FT 50, Hong translation emended).

The aesthete manages to achieve a kind of harmony with existence by perfecting the art of being able to recollect and forget at will, but this comes at the cost of having to eschew every 
serious commitment. The knight of faith is able to do the same thing but without throwing commitment overboard: 'To live happily every moment this way by virtue of the absurd, every moment to see the sword hanging over the beloved's head, and yet not to find rest in the pain of resignation but to find joy by virtue of the absurd - this is wonderful' (ibid.). But how does one live 'by virtue of the absurd' if this is not tantamount to the view that God will somehow make possible the fulfilment of impossible wishes? And since we have already seen that it is not, why use the term 'absurd' at all?

I believe that there are two reasons for Johannes' inflated use of rhetoric. The first is that he just cannot understand how one might become a person of faith, rather than someone who takes refuge in the pain of resignation; the second is that Johannes is conducting his discussion in a Hegelian context that has made faith into a cheap, immediate commodity that can easily be acquired ${ }^{31}$. In his zeal 'to make difficulties everywhere', as his alter ego Johannes Climacus, would say, de Silentio therefore ends up overstating the case: he makes faith out to be something that appears to resist intellectual understanding ${ }^{32}$.

But it is not that faith is impossible to understand ${ }^{33}$, because it requires espousing mutually inconsistent belief-attitudes at the same time. This is a confusion that de Silentio himself at times succumbs to. Rather, what is difficult is to become the kind of person who is capable of expressing the sublime in the pedestrian, and this is not an intellectual problem, but a spiritual one. To become the kind of person who does not see suffering and the general impossibility of human happiness as an objection to existence (and to God) is a spiritually demanding exercise, which may well strike one as absurd when in the grip of intense suffering. Consequently, it requires efforts similar to (but transcending) those made by the aesthete. For, as we have already seen, both the aesthete and the knight of faith need to relate to actuality in the right way, instead of ultimately fleeing from it like the knight of infinity. The aesthete is able to make life beautiful by seeing every moment as an occasion for 
aesthetic opportunity, something that is made possible by maintaining an equilibrium between not caring too much about the finite and not caring too little. Caring too much is a sign that one has not genuinely thrown hope overboard, caring too little a sign that one is heading down the road to infinite resignation (or, perhaps, even worse, utter cynicism that cannot even appreciate beauty).

A similarly delicate - but different - balancing act is necessary in the world of faith. As Johannes Climacus tells us: 'the appointed task is simultaneously to relate oneself absolutely to the absolute telos and relatively to relative ends' (CUP 431). In order to be able to fulfil this task, however, an individual must practice the renunciation of finite ends, otherwise he (or she) will remain stuck in immediacy - will continue to have their whole life in worldly joys and sorrows (CUP 432), a recipe for disaster as soon as things go wrong. Nevertheless, what Climacus is emphasizing here is that the required 'dying to immediacy' relating to finite ends relatively - is not a separate movement that precedes faith. Rather, faith is a task that consists of simultaneously relating oneself relatively to the finite and absolutely to the absolute (what this means will be discussed below) ${ }^{34}$. In other words, the so-called 'double movement' of faith is really one single movement where 'having' the finite and 'giving up' the finite ultimately become indistinguishable from one another in the same way that recollecting and forgetting become expressions for one and the same thing in the case of the aesthete.

The metaphor of the ballet dancer already gives us a clue to the correctness of this reading (despite the fact that Johannes himself seems, at times, to draw the wrong conclusions from his example). For a leap does not consist of two discrete, linear movements - leaping up and then, as it were, jumping down again. Rather, how one lands is a function of how one leaps. So, if one leaps in the right way - with the right kind of elevation and one's centre of gravity in the right place - then one will also be able to land without a wobble, as 
does the knight of faith. If one leaps, on the other hand, only paying attention to one's elevation (because one wants to escape the finite, say) and not to one's centre of gravity that is to say, if one jumps up but with one's weight back - then one will not be able to assume one's landing position with ease. This shows that, right from the beginning, the knight of infinite resignation and the knight of faith do different things: they both leap, but in completely different ways. The knight of faith's centre of gravity is the absolute telos (God), and so his weight is in the right place, whereas the knight of infinite resignation's weight is too far back, because his centre of gravity is himself (that is to say, he is too concerned with his own self and with protecting it from pain).

If this is right, then, contrary to what de Silentio claims, the knight of faith does not make one more movement - or, pace Hall and Lippitt (2003), annuls his first movement - he rather performs a movement that looks similar to the other knight's, say, to stay with the ballet metaphor, because they are both trying to execute a grand pas de chat, but their leaps nevertheless have completely different qualities. Consequently, the resignation that is an element of faith is not a separate, prior movement like infinite resignation. Rather, it constitutes that aspect of faith which relativizes the finite through an awareness of the ultimate futility of every human project (that however hard we strive, whatever we attempt can, in an instant, come to naught), while its simultaneous dimension of joy is expressed in the ability not to regard this fact as an objection to existence (or to God). In this respect, the knight of faith has something important that the aesthete lacks, and that therefore transforms his whole attitude to the world - trust and the ability to regard life as a whole as a gift. It is for this reason that the knight of faith does not need 'miserable hope', since trust is better than hope: 
It so happens that he [the knight of faith] does not have four shillings to his name, and yet he firmly believes that his wife has this delectable meal waiting for him. If she has, to see him eat would be the envy of the elite and an inspiration to the common man, for his appetite is keener than Esau's. His wife does not have it - curiously enough he is just the same (FT 40, Hong translation).

Commentators generally struggle with this description of Johannes's imaginary, contemporary knight of faith ${ }^{35}$. Even Hanson (2017), whose overall account of FT has much to recommend it, doesn't get it quite right. Hanson says, 'What the knight of faith actually expects, what he hopes for, is not exactly any given actuality, be it lamb's head or tinned meat, but an intensification of relationship that is betokened by the availability of the dinnertime meal, regardless of what that meal actually turns out to be. What he expects is ongoing intimacy with his wife, which is both indicated and fostered by the proffering of the meal' (2017:109).

Although I'm sure that there is something right about this depiction too, the contemporary knight of faith is not disappointed by the frugal meal his wife offers him, because he expects something else instead; namely, an intensification of relationship. Rather, 'he is just the same,' as he does not will any finite end absolutely. That is to say, he relates to everything he receives in life as a freely bestowed gift, and as consequently constituting something that he has no right to expect. But this is compatible with nevertheless preferring a meal of lamb's head.

So, Hanson is right that the knight of faith does not expect (demand) any given actuality, but wrong to think that this is because intimacy with his wife is more important to him than lamb's head (even if that is also true). Gifts are freely given or not given, and this is 
how the knight of faith relates to actuality: he is happy if his wife has the gift of lamb's head, but he is not disappointed if she doesn't (for no one has a right to expect gifts). For this reason, the knight of faith is able, in principle, to come to terms with any outcome, even the ones he finds existentially challenging.

Consequently, Johannes is right when he says that Abraham has faith - trusts God that he will not have to sacrifice Isaac, while nevertheless being willing to give him up if he must $^{36}$. For being prepared, if push comes to shove, to sacrifice someone (or something) is not the same thing as believing that this person (thing) will actually be taken from one (de Silentio sometimes seems to conflate this distinction).

Hence, on my interpretation, Abraham only believes one thing - he has faith that Isaac will be spared ${ }^{37}$. But this is compatible with Abraham's nevertheless not willing his own wishes absolutely and instead putting his life, and the life of his son, into the hand of God. In this respect, Abraham leaves everything up to God - to the point of drawing the knife - while at the same time trusting that Isaac will not be harmed ${ }^{38}$.

It is because the knight of faith has this trust - which one might call trust in an 'absolute' sense ${ }^{39}$ - that he does not need hope. For we hope for the things that we will absolutely - the things that would devastate us if we didn't get (or retain) them ${ }^{40}$. But the knight of faith wills nothing absolutely except life itself which he regards as a freely given gift from God. Consequently, he hopes for nothing, as whatever he gets is, in a sense (and as previously discussed), what he wants ${ }^{41}$.

In this respect I disagree with Lippitt, who thinks that the knight of faith retains hope (2003: 75). For hope and 'absolute trust' are not really compatible, since if one trusts in this way, one does not need hope. To be fair to Lippitt, in the revised second edition of his (2003), he calls this hope, following Lear (2008), 'radical hope' (Lippitt 2016: 187-207), and he takes 
care to distinguish it from the 'miserable' or 'despicable' variety we encountered before. He also relies heavily on the upbuilding discourse 'The Expectancy of Faith' in Eighteen Upbuilding Discourses, published in the same year as FT. But the interesting thing about this discourse is that it doesn't underwrite Lippitt's interpretation, as 'hope' hardly figures in it; rather, what it is centred around is the idea of expectancy - the thought that faith always expects 'victory', but in a 'higher', not an 'external' sense.

What this means is that what Kierkegaard calls 'the expectancy of faith' is compatible with any outcome in the external world, including the most appalling ones, such as Job's situation, for example. This sits uneasily with the claim that Lippitt takes over from Lear that 'My commitment to God's transcendence and goodness is manifested in my commitment to the idea that something good will emerge even if it outstrips my present limited capacity for understanding what that good is' (Lippitt 2016: 189, italics in original). For Job retains his faith (despite his initial quarrel with God) even after he has lost everything, and is no longer expecting that anything good will emerge at all $^{42} .43$

It is also hard to see how 'radical hope' might apply to an inmate of Auschwitz, for instance, who miraculously managed to retain his faith despite being witness to the complete disintegration of humanity. Did he manage to do this because he was expecting 'some good', however unspecified, to come out of his experience? I think it would be cynical to say this. The mere fact that the 'good' in question is not a 'specific' good, as Lippitt (2016: 191) emphasizes, does not suffice to dispel such fears.

Bernier (2015: 212-13), on the other hand, equates trust and hope, which also seems problematic given that he identifies 'authentic' hope with a belief in the Christian afterlife, something that doesn't figure in FT at all (as Bernier himself admits (2015: 213)). 
Furthermore, this would be hope for something like a specific outcome, and therefore not a plausible candidate for Abraham's attitude ${ }^{44}$.

My reading, on the other hand, is able to avoid these problems, as, on my interpretation, the knight of faith humbly accepts whatever is given to him - including, like Job, the terrible and devastating - without seeking to flee from it, or to hope for a better outcome in this world (or the 'next'). It is in this 'internal', 'infinite' (FT 47) sense that faith is always 'victorious': it ensures (spiritual) victory by transforming the whole of existence into something sacred.

This perspective the knight of infinity lacks. For infinite resignation is really the renunciation of a relative telos - such as an earthly love - that one regarded as absolute (and that consequently leads to a complete disenchantment with the finite), whereas faith has the 'humble courage'45 (FT 49) to affirm life in despite of human suffering and loss.

Similarly, the lad who is a knight of faith, is going to continue to have faith that he might have the princess in despite of all worldly calculations that would make this seem unlikely. Nevertheless, and this is where the element of resignation comes in that Johannes confuses with infinite resignation, the knight of faith will not despair even if his wish is not fulfilled. In this sense, and as de Silentio has already emphasized, the 'having' of faith is also a kind of 'giving up' (FT 47).

It is this courage that Johannes de Silentio appears to lack (which is why he describes himself as an outsider to faith $^{46}$ ), preferring instead the peace and security that infinite resignation seems to bring (FT 50). The knight of faith, on the other hand, has the strength to acknowledge the full extent of worldly impossibility, but rather than taking this as reason to return the lottery ticket, continues, joyfully, to play in the knowledge that, at any moment, he could lose. De Silentio puts it thus: 'With infinite resignation ${ }^{47}$ he [the knight of faith] has 
drained the cup of life's profound sadness, he knows the bliss of the infinite, he senses the pain of renouncing everything, the dearest things he possesses in the world, and yet finiteness tastes to him just as good as to one who never knew anything higher, for his continuance in the finite did not bear a trace of the cowed and fearful spirit produced by the process of training; and yet he has this sense of security in enjoying it, as though the finite life were the surest thing of all' (FT 40).

In other words, the knight of faith continues to will (to strive), but has nevertheless found a way of accepting what happens regardless of the outcome. He (or she) is able to do this because resignation has taught him (or her) not to place an absolute value on finite ends, and to relate absolutely only to God. In this respect, not to rebel against the will of God means not to regard one's own will and the satisfaction of one's own desires as of paramount importance and as something that one somehow has a right to ${ }^{48}$. It is for this reason that the knight of faith is able to say with Job, 'The Lord has given, the Lord has taken away, blessed be the name of the Lord' $\left(\right.$ Job 1:21) ${ }^{49}$.

Perhaps it is also this stance that Wittgenstein had in mind when, in the Lecture on Ethics, he speaks of feeling 'absolutely safe'. For although the knight of faith knows that he can be harmed in any worldly sense, he nevertheless feels 'safe' in the hands of God - he feels that, from a spiritual point of view, he can never come to grief.

\section{Conclusion}

If what I have argued in this paper is correct, we need to reject a 'linear' account of faith: in order to have faith, one does not need to pass through infinite resignation first (or strive 
constantly to 'annul' it). Rather, one needs to become adept at taking a spiritually demanding attitude to life and the world that consists of unflinching awareness of the fragility of human happiness, but which simultaneously expresses itself as 'the most beautiful and assured harmony' with existence ${ }^{50}$.

Faith, in other words, is an art, for as Climacus says, 'to exist is an art' (CUP 351). The knight of faith is therefore just as much (or more of) an 'artist of life' as (than) the aesthete is. Both are 'poets of possibility' who seek to make life beautiful; the knight of infinite resignation, on the other hand, has lost faith in possibility altogether. But while the aesthete remains stuck in his purely aesthetic world (since he rejects all commitments), which, arguably, is just one more sophisticated attempt at trying to avoid the painfulness of existence (like infinite resignation), the knight of faith has the courage to affirm life despite human suffering and loss 51 .

\section{References}

Bernier, M. (2015), The Task of Hope in Kierkegaard (Oxford: Oxford University Press).

Carlisle, C. (2010), Kierkegaard's Fear and Trembling (London: Bloomsbury).

Cross, A. (1999), 'Fear and Trembling's Unorthodox Ideal', Philosophical Topics, 27 (2): 227-53).

Davenport, J. J. (2008), 'Faith as Eschatological Trust in Fear and Trembling' in E. F. Mooney (ed.), Ethics, Love and Faith in Kierkegaard: Philosophical Engagements, (Indiana: Indiana University Press), 196-233. 
Davenport, J. J. (2015), 'Eschatological Faith and Repetition: Kierkegaard’s Abraham and Job', in D. W. Conway (ed.), Kierkegaard's Fear and Trembling: A Critical Guide (Cambridge: Cambridge University Press), 79-105.

Hall, R. (2000), The Human Embrace: The Love of Philosophy and the Philosophy of Love: Kierkegaard, Cavell, Nussbaum (University Park, PA: Pennsylvania State University Press).

Hanson, J. (2017), Kierkegaard and the Life of Faith (Bloomington and Indianapolis: Indiana University Press).

Hough, S. (2006), 'What the Faithful Tax Collector Saw (Against the Understanding)', in International Kierkegaard Commentary: 'Without Authority,' ed. Robert L. Perkins (Macon, GA: Mercer University Press).

Kierkegaard, S. (1980), The Sickness unto Death, ed. and trans. Howard and Edna Hong (Princeton: Princeton University Press, 1980)

Kierkegaard, S. (1983), Fear and Trembling, ed. and trans. Howard and Edna Hong (Princeton: Princeton University Press).

Kierkegaard, S. (1985), Fear and Trembling, trans. Alistair Hannay (London: Penguin).

Kierkegaard, S. (1988), Either/Or I and II, ed. and trans. Howard and Edna Hong (Princeton: Princeton University Press).

Kierkegaard, S. (1992a), Concluding Unscientific Postscript to Philosophical Fragments, ed. and trans. Howard and Edna Hong (Princeton: Princeton University Press).

Kierkegaard, S. (1995), Works of Love, ed. and trans. Howard and Edna Hong (Princeton: Princeton University Press, 1995).

Lear, J. (2008), Radical Hope (Cambridge, MA: Harvard University Press). 
Lippitt, J. (2003, 2016), Routledge Guidebook to Kierkegaard's Fear and Trembling

(London: Routledge).

Mooney, E. F. (1991), Knights of Faith and Resignation: Reading Kierkegaard's Fear and

Trembling (Albany: State University of New York Press).

Mulhall, S. (2003), Inheritance and Originality (Oxford: Oxford University Press), pb.

Schönbaumsfeld, G. (2007), A Confusion of the Spheres. Kierkegaard and Wittgenstein on

Philosophy and Religion (Oxford: Oxford University Press).

Westphal, M. (2014), Kierkegaard's Concept of Faith (Grand Rapids, Mich.: Eerdmans).

Wittgenstein, L. (1993), 'Lecture on Ethics', in J.C. Klagge and A. Nordmann (eds),

Wittgenstein: Philosophical Occasions (Indianapolis: Hackett).

${ }^{1}$ Concluding Unscientific Postscript to Philosophical Fragments, 457.
2 See, for example, Mooney (1991).
${ }^{3}$ See also the discussion of this problem in Lippitt (2016: 73-82).
${ }^{4}$ Also quoted in Lippitt (2016: 78).
${ }^{5}$ Hanson (2017) also rejects 'linear models' of faith (including the 'annulled possibility' ones, see, e.g. Hall (2000) and Lippitt (2003/2016)), but our overall interpretations differ. See discussion in text below as well as the next footnote.

${ }^{6}$ Hall argues that 'infinite resignation' is a constant possibility that the knight of faith must strive continuously to annul (2000: 33-37). There is something right about this, if we bear in mind, as I shall argue, that resignation is an element of faith, but that this is different from the stance of the knight of infinity, who is the exemplar of infinite resignation. Hall does not make a distinction between resignation and infinite resignation, and this makes it hard for him to avoid the paradox. Also see Lippitt 2003 and his revised, second edition 2016. Lippitt's new view will be discussed in more detail in section III.

${ }^{7}$ In this I am not alone. Lippitt (2016), Davenport (2015) and Mulhall (2003) also do this (among others).

${ }^{8}$ That is to say, he claims he wanted to write these works but was, alas, beaten to it by the various pseudonymous authors, including one Magister Kierkegaard (CUP 251)!

${ }^{9}$ I am not thereby suggesting that Don Giovanni and Johannes the Seducer are the same person. They are completely different and represent different forms of aestheticism - 'immediate' and 'reflective' respectively. Nevertheless, they are both aesthetes and throw light on each other, which may be the reason why Kierkegaard gave them the same name. But if this seems forced to the reader, it can be ignored. Nothing in the interpretation I will advance in this paper depends on accepting it.

${ }^{10}$ That 'John' is a common name is not an objection to this, as Kierkegaard specifically chose this name. However, even if the commonality is less significant than I think, important parallels can nevertheless be discerned between the aesthete's approach to life and that of the knight of faith. Since Johannes Climacus is arguably Kierkegaard's highest, non-Christian pseudonym, the either/or that he sets up between the aesthetic and the religious (see motto) also needs explanation. Furthermore, given his status, it is legitimate to look at what he says about faith to help us understand what de Silentio is saying. Other commentators also appeal to other Kierkegaardian texts to help explicate FT. Lippitt (2016), for example, appeals extensively to the 
discourse 'The Expectancy of Faith', Works of Love and The Sickness unto Death. Hall also bases much of his reading around the latter (2000: 36). Mulhall (2003: 356) thinks the two Johanneses (de Silentio and Climacus) 'are different and yet the same', something that seems corroborated by Climacus' ironic remark that it is commonly supposed that the pseudonymous authorship is by one person (CUP 284).

${ }^{11}$ Hannay's translation (the Hongs have 'despicable').

12 Lippitt (2016: 176) contrasts this 'miserable hope' with the attitude that he wants to defend, which he calls 'radical hope'. I discuss Lippitt's view in section III.

${ }^{13}$ I do not, by saying this, wish, in any way, to downplay the differences between aestheticism and faith. The two attitudes are clearly fundamentally different. Nevertheless, my point is that they share a common structure an understanding of which sheds light on the nature of faith.

${ }^{14}$ The so-called 'theory of social prudence' expounded by A in the chapter 'Rotation of Crops' is, of course, not a theory, but an ironic gibe at Hegel who, according to Kierkegaard, was of the misguided view that a philosophical system could give someone a recipe for how to live.

${ }^{15}$ The Lecture on Ethics in Philosophical Occasions, ed. James Klagge and Alfred Nordmann (Indianapolis: Hackett, 1993), p. 40.

${ }^{16} \mathrm{I}$ 'm here merely reporting, not assessing, the aesthete's views as they emerge from volume one of Kierkegaard's Either/Or.

${ }^{17}$ This is not to reimport absolute values, as the aesthete's endeavour is an existentially solipsistic one that does not lay claim either to universal or to intersubjective aesthetic validity. For the aesthete does not seek to convince anyone else of the superiority of his aesthetic pursuit.

${ }^{18} \mathrm{I}$ 'm going to treat $\mathrm{A}$, the ostensible author of the papers that form volume I of Either/Or, and Johannes, the author of the notorious 'Seducer's Diary', as essentially being one and the same person. The penultimate chapter of volume I, 'Rotation of Crops', penned by A, provides the 'theory' that Johannes then goes on to put into practice and records in his diary, so nothing much seems to hang, interpretatively, on treating $A$ and the author of the Seducer's Diary as two different people. It rather seems that A is afraid of his own production and therefore attributes it to another pseudonymous 'friend'.

${ }^{19}$ As A says in the section entitled 'Either/Or' of the 'Diapsalmata', the true 'eternity' lies before 'either/or' all possibilities as it were remain eternally open to one if one never commits to any of them.

${ }^{20}$ Of course, there may be certain limits to this - torture, say.

${ }^{21}$ And should this prove impossible, as I need, for example, to take a job in order to survive, then I need to remain ironically detached from my breadwinning endeavours even while acting as a model employee, say. ${ }^{22}$ All references to the Hong translation unless otherwise indicated.

${ }^{23}$ The Danish word not only means sitting on the side-lines or on the bench, but also, in Kierkegaard's time, had the connotations of having to repeat a year in school or being given a detention (similar to the German word 'nachsitzen').

${ }^{24}$ Compare Hanson (2017: 90-127).

${ }^{25}$ So I agree with Hall (2000: 36 ) that infinite resignation is a form of despair, but disagree that this despair is necessary for faith. What is necessary is a form of resignation that consists in relating to the finite relatively, but this is not a form of despair. See discussion below.

${ }^{26}$ Reference to the Hannay translation, because I prefer 'miserable' to the Hongs' 'despicable'.

${ }^{27}$ For more on Kierkegaard's conception of faith, see my A Confusion of the Spheres.

${ }^{28}$ In this respect I agree with Lippitt (2003: 196-205), and contra Mulhall (2003: 370-6), that Johannes is not deliberately leading the reader astray - he just gets some (not all) things wrong, as he is an outsider to faith.

${ }^{29}$ If de Silentio intended the deus ex machina view, this would be inexplicable.

${ }^{30}$ This is the significance of the epigraph by Hamann which provides the motto for FT: 'What Tarquinius

Superbus said in the garden by means of the poppies, the son understood but the messenger did not.' On my reading Johannes is the messenger who often does not understand the message that he is conveying (compare Lippitt 2003: 197).

${ }^{31}$ I leave open whether Johannes is right about this.

${ }^{32}$ Compare Mulhall (2003: 382). For other commentators who think that dubbing faith 'absurd' constitutes a view from outside faith, see Evans (1993: 25), Lippitt (2003: 55-57), and Mooney (1991: 54-6).

${ }_{33}$ Pace, for example, Magnus Eriksson (an early reviewer of FT), who thought that Kierkegaard was propagating the view that faith is literally absurd (see FT 262).

${ }^{34}$ In this respect, the knight of faith's conception is similar to what Climacus calls 'religiousness $A^{\prime}$ in CUP. This should not surprise us, given that Abraham's faith is not specifically Christian faith, and should not be 
conflated with the conceptions advocated by Anti-Climacus or Kierkegaard in Works of Love (although there may be similarities - something, however, that I cannot explore here).

${ }^{35}$ See, in particular, Hough (2006: 298), who attributes a false belief to the knight, which is widely off target.

${ }^{36}$ For the purposes of this paper I remain agnostic on the question whether faith requires a 'teleological suspension of the ethical'. Neither am I going to discuss the issue of whether it was justifiable for Abraham to be in principle willing to do this, or whether we are meant, by Kierkegaard, to take the Abraham story literally as opposed to allegorically (for an interesting, allegorical reading, see Mulhall (2003)). I am here solely interested in the question of what the relation between infinite resignation and faith is, and whether the latter requires the adoption of inconsistent belief-attitudes. Once we have got this straight, we can apply these insights to a reading of FT as whole, which, however, is beyond the scope of this paper.

${ }^{37}$ Here I am in agreement with Lippitt (2003: 69).

${ }^{38}$ It is this attitude which can strike one as 'absurd', but on my interpretation this is because it is so spiritually demanding, not because it 'annuls' the prior attitude of infinite resignation or requires belief in an impossibility. To reiterate, Abraham is prepared to go through with the sacrifice if he must, while having faith (trusting) that he will not have to. This is quite different from both believing and not believing that he must sacrifice Isaac.

39 'Absolute trust' is qualitatively different from ordinary, 'relative' forms of trust that can easily be disappointed if one's trust isn't rewarded. For Abraham always trusts God. His trust is not contingent on what God does (perhaps some forms of parental love are also like this - for example, a mother trusting that her son is not guilty in spite of what the facts seem to suggest). I remain agnostic on whether such an attitude is 'reasonable'.

${ }^{40}$ In ordinary circumstances, we hope for all sorts of other, more mundane things too (such as getting a particular job, having a pay rise etc.). But FT does not concern itself with them, as these would be the hopes of the 'benchwarmers' (the slaves of the finite) that neither the knight of infinite resignation nor the knight of faith has any time for.

${ }^{41}$ In this way faith transforms the mindset of the bourgeois philistine who espouses the most prudential outcome.

${ }^{42}$ The discourse on Job, 'The Lord Gave, the Lord Took Away; Blessed Be the Name of the Lord', also published in the same year as 'The Expectancy of Faith' and Fear and Trembling, makes this very clear.

${ }^{43}$ And it is only after Job responds in this 'faithful' way that God restores everything to him. Job was not 'expecting' this outcome; if he had, it would have been self-interest, not faith, and Kierkegaard would have had no time for him.

${ }^{44}$ For similar reasons, Davenport's 'eschatological trust' (2008) is also problematic, as this, too, is tied to the idea of life after death and de Silentio makes it quite clear that 'his (the knight of faith's) faith was not that he should be happy sometime in the hereafter, but that he should find blessed happiness here in this world' (FT 65; Hannay translation). Also see Westphal's (2014) objections to Davenport and Davenport's response (2015). I do not have the space to explore this point further here.

${ }^{45} \mathrm{~A}$ 'humble' courage is needed because it requires one confront the thought that the fulfilment of one's wishes is only relatively - not absolutely - important (for a different reading, see Carlisle (2010: 193-99)). ${ }^{46}$ Compare Lippitt (2003: 39-41).

${ }^{47}$ Johannes should have said 'resignation' here, as infinite resignation is a different attitude (as I have argued).

${ }^{48}$ What it does not imply, pace Mooney, is that one stops caring about those one loves (quite the reverse).

${ }^{49}$ Here FT makes obvious contact with the book published alongside it, Constantin Constantius' Repetition, which revolves around Job's ordeal. This is not accidental, as Job and Abraham are similar to each other and tried by God in similar ways. But whereas Abraham always already responds to God's demands with absolute trust, Job first has to learn this stance the hard way. For a good discussion of this, see Mulhall (2003: 405-9).

${ }^{50}$ I remain agnostic on the issue of whether we should espouse such a conception, or, indeed, whether we can (de Silentio has already admitted that he cannot).

${ }^{51}$ I would like to thank an anonymous referee for their extremely useful comments and suggestions. 